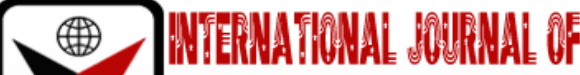

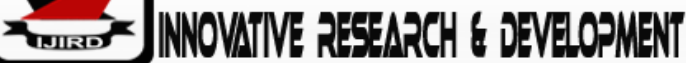

ISSN 2278 - 0211 (Online)

\section{'Fast' Strategy of TB Infection Control: Comparative Knowledge and Attitude of Health-Workers in Tertiary Health Institutions in Abia State, Nigeria}

Iwuoha Ejiro Carol
Consultant Physician, Department of Community Medicine,
Abia State University Teaching Hospital, Nigeria
Okorie Onuka
Program Manager, Department of Tb Control Unit,
Abia State Ministry of Health, Umuahia, Nigeria
Gidado Mustapha
Executive Director, Department of Technical /Strategic Unit
Kncv, The Hague, Netherlands
Nkpozi Marcellinus
Consutlant Physician, Department of Internal Medicine,
Abia State University Teaching Hospital, Nigeria

\begin{abstract}
:
Background: Tuberculosis (TB) though a long existent disease still constitutes a major public health problem in Nigeria. TB burden in Nigeria is one of the highest in the world (318 per 100,000) but case detection rate (16\%) is one of the lowest globally. A key strategy for active case finding and TB infection control (TBIC) is the 'FAST' strategy. FAST stands for Finding (TB cases), Actively, Separating and Treating.

Methods: This was a cross-sectional study of 148 health-workers in the two tertiary health institutions in Abia state (Federal Medical Centre Umuahia (FMCU) and Abia State University teaching Hospital (ABSUTH)) Aba. Seventy-four consenting health workers from each facility were proportionately selected through stratified random sampling. Pretested self-administered questionnaires were administered on them. Knowledge scores were computed using 16 parameters while attitude was computed using 6. Knowledge and attitude were classified as good or poor. Data was analysed using SPSS version 22.

Results: Among ABSUTH staff, 56(75.7\%) had poor knowledge (across cadres of health-workers). Health-workers at FMCU had statistically significant higher knowledge $(p=0.01)$ than ABSUTH staff though majority; 47(63.5\%) also had poor knowledge of the FAST strategy. For attitude towards the strategy, overall, 56(75.7\%) of health workers in ABSUTH had good attitude similar to that of FMCU; 57(77.0). Previous attendance at a TB training was found to be a predictor of good knowledge aOR 2.81; 95\% CI (1.01-7.99) while age was found to be associated with good attitude aOR 9.68; 95\% CI (1.01-92.8).

Conclusion/ Significance: Despite the relevance of the 'FAST' strategy to TB case detection and TBIC, the study demonstrated poor knowledge among these health workers. The need for health-workers training and re-training on TB is imperative.
\end{abstract}

Keywords: FAST strategy, tuberculosis, health-workers, knowledge, attitude

\section{Introduction}

Tuberculosis (TB) is a communicable disease that is a major cause of ill health, one of the top 10 causes of death worldwide and the leading cause of death from a single infectious agent (ranking above HIV/AIDS). TB is caused by the bacillus Mycobacterium tuberculosis, which is spread when people who are sick with TB expel bacteria into the air; for example, by coughing. The 'disease typically affects the lungs (pulmonary TB) but can also affect other sites (extrapulmonary TB)[1].

Evidence abound that TB is curable and preventable. Treatment has the additional benefit of curtailing onward transmission of infection [2]. In 2014 and 2015, all Member States of WHO and the UN committed to ending the TB epidemic, through their adoption of WHO's End TB Strategy and the UN Sustainable Development Goals (SDGs). The strategy and SDGs include milestones and targets for large reductions in TB incidence, TB deaths and costs faced by TB 
patients and their households [3]. In September 2018, the UN General Assembly held its first-ever high-level meeting on TB that ended with a political declaration in which commitments to the SDGs and End TB Strategy were reaffirmed [4].

Globally, an estimated 10.0 million (range, 8.9-11.0 million) people fell ill with TB in 2019, a number that has been declining very slowly in recent years. [5]. The laboratory diagnosis of TB rests mainly on the identification of the tubercle bacilli in a clinical specimen by using microscopy, culture or newer molecular tests e.g., GeneXpert MTB/RIF and line probe assays [6].

FAST strategy is a focused approach to stopping TB spread in congregate settings It is a strategy developed in 2013 by TB CARE 11 with the support of United State Agency for International Development (USAID) [7]. The strategy was adopted by the National Tuberculosis Leprosy and Buruli ulcer Control Programme (NTBLCP) in 2014 [8]. FAST' focuses attention on implementing and monitoring the administrative processes and procedures necessary to find and rapidly diagnose unsuspected infectious TB and drug resistant TB cases, such that effective therapy may start within days, not weeks or months [7]. The FAST strategy as a tool for TB infection control is new to the NTBLCP which raises the concern about the knowledge of the health workers on the strategy and indeed TB infection control. In a study on the assessment of knowledge and practice of health workers towards tuberculosis infection control and associated factors in public health facilities of Addis Ababa, Ethiopia, it was observed that one third of the health workers lacked knowledge of TB infection control [9] ...Worrisome is the fact that the risk of transmission of TB to health workers is double that of the general population [10].

Furthermore, in a study on current practices and barriers to the use of facemasks and respirators among hospitalbased health care workers in Vietnam, knowledge of the harmful effects of the reuse of cloth face masks was lacking amongst some health workers [11]. The variability in reuse practices by these workers cannot be totally separated from their knowledge. In addition, a study in Russia on TBIC amongst health care workers identified knowledge deficit as one of the major barriers [12]. In another study among healthcare workers in Southern Ethiopia, knowledge about TB screening, diagnosis and treatment was positively associated with case notification (aOR 2.53, 95\%CI 1.42-4.48) [13].

The FAST Strategy was introduced in Nigeria in 2014. Abia State health-workers in both tertiary health institutions were trained on implementation of the strategy in 2015. This study therefore sought to assess the knowledge and attitude of the health workers towards the strategy and TBIC one year after it was introduced in these institutions.

\section{Materials and Methods}

This was a facility based Comparative cross sectional study involving staff of two tertiary health institutions in Abia State; Federal Medical Centre Umuahia (FMCU) and Abia State University teaching hospital Aba (ABSUTH). Both Institutions have similar cadre of Staff and provide tertiary level of care with specialists in various disciplines of Medicine. Staff included in the study were; Doctors and nurses providing direct patient care, Laboratory scientist/technicians responsible for diagnosing TB and MDRTB and Medical Record officers who issue cards and are usually first to see the patients and thus can identify and separate coughing patients as practiced under the 'FAST' strategy [8]. A minimum sample size of 64 staff per institution was statistically determined for the study using the sample size formula for comparing two proportions (independent samples) [14] and an attrition rate of $10 \%$. However, a total of 148 staff were included in the study. The sample size was proportionately assigned to the included groups of health workers in the General outpatient, laboratory, HIV clinic, TB unit, medical records and medical wards.

Information on health workers demographics, knowledge and attitude in both study facilities were obtained using pretested self-administered semi-structured questionnaires. Questionnaires were administered to the selected participants at a training on workplace hygiene organised by the researchers. Knowledge was assessed using 16 questions. Scores were computed manually for each respondent. Giving correct answer earned a score of 1 if not a score of 0 . Knowledge score for individuals was calculated. Knowledge was classified as good if it was 50\% of the expected maximum score or above.; scores below 8 were classified as poor. Attitude was assessed using 6 questions. Giving correct answer earned a score of 2 while an incorrect answer was scored as zero. Attitude was classified as good if the respondent had a score of 8 and above while scores below 8 were scored as poor attitude.

Chi- square test was used to test for statistical differences of knowledge and attitude between the two groups. Predictors of knowledge and attitude (Dependent variables) were analysed with the socio-demographic characteristics (Independent variables: age, gender, Cadre, educational status and previous attendance of TB training) using univariate logistic regression. Independent variables that were significant at $10 \%$ in the univariate analysis or found to be associated in previous literature were included in the multivariate regression model. Ethical approval for the study was obtained from the Research and Ethics Board of Abia State University Teaching Hospital (ABSUTH), Aba. Permission to carry out the study was obtained from the management of both facilities. Individual consent forms were obtained from participants after explaining to them the nature of the research and assurance of confidentiality of information given.

\section{Results}

A total of 148 health workers were studied (74 from each health institution) to assess their knowledge, and attitude on the 'FAST' strategy of TB infection control. 


\begin{tabular}{|c|c|c|c|c|c|}
\hline Characteristic & ABSUTH & FMCU & Total & Statistics & p-value \\
\hline & $\begin{array}{c}\mathrm{N}=74 \\
\mathrm{n}(\%)\end{array}$ & $\begin{array}{c}\mathrm{N}=74 \\
\mathrm{n}(\%)\end{array}$ & $\begin{array}{c}\mathrm{N}=148 \\
\mathrm{n}(\%)\end{array}$ & & \\
\hline \multicolumn{6}{|l|}{ Age Group(Years) } \\
\hline $20-29$ & $9(12.2)$ & $6(8.1)$ & $15(10.2)$ & & \\
\hline $30-39$ & $18(24.3)$ & $27(36.5)$ & $45(30.4)$ & & \\
\hline $40-49$ & $32(43.2)$ & $24(32.4)$ & $56(37.8)$ & & \\
\hline $50-59$ & $15(20.3)$ & $17(22.0)$ & $32(21.6)$ & & \\
\hline (Mean age) $\pm \mathrm{SD}$ & $41.34 \pm 8.7$ & $40.38 \pm 8.5$ & & $t=0.681$ & 0.497 \\
\hline \multicolumn{6}{|l|}{ Gender } \\
\hline Male & $21(28.4)$ & $20(27)$ & $41(27.7)$ & \multirow[t]{2}{*}{$\chi^{2}=0.281$} & \multirow[t]{2}{*}{0.596} \\
\hline Female & $53(71.6)$ & $54(73)$ & $107(72.3)$ & & \\
\hline \multicolumn{6}{|l|}{ Cadre } \\
\hline Doctors & $20(27)$ & $20(27.0)$ & $40(27.0)$ & & \\
\hline Nurses & $32(43.2)$ & $32(43.2)$ & $64(43.2)$ & & \\
\hline Lab Scientist/technicians & $14(18.9)$ & $14(18.9)$ & $28(18.9)$ & $\chi^{2}=0.00$ & 1.00 \\
\hline Medical records officers & $8(10.8)$ & $8(10.80)$ & $16(10.8)$ & & \\
\hline \multicolumn{6}{|l|}{ Highest Educational level } \\
\hline Secondary & $0(0.0)$ & $3(2)$ & $3(2)$ & \multirow[t]{3}{*}{$* * \mathrm{FT}=2.96$} & \multirow[t]{3}{*}{0.26} \\
\hline $\mathrm{SN} / \mathrm{SM} / \mathrm{SH}^{*}$ & $16(21.6)$ & $18(24.3)$ & $34(33.0)$ & & \\
\hline Other tertiary & $58(78,4)$ & $53(71.6)$ & $111(75)$ & & \\
\hline \multicolumn{6}{|l|}{ Ever attended TB training } \\
\hline Yes & $27(36.5)$ & $34(45.9)$ & $61(41.2)$ & \multirow[t]{2}{*}{$\chi^{2}=1.366$} & \multirow[t]{2}{*}{0.242} \\
\hline No & $47(63.5)$ & $40(54.1)$ & $87(58.9)$ & & \\
\hline
\end{tabular}

Table 1: Characteristic of the Health Workers

*School of Nursing/School of Midwifery/School of Health Technology ${ }^{* *}$ FT=Fishers Exact Test

Table 1 describes the general characteristics of all the health workers in the study in terms of age, gender, cadre, education and previous attendance at TB training. There was no statistically significant difference $(p>0.05)$ in age of respondents between groups. A higher number of health workers 34(45.9\%) in the FMCU group had attended TB training in the past compared to $27(36.5 \%)$ in the study group. This was however not statistically significant between groups (p> 0.05).

\begin{tabular}{|c|c|c|c|c|c|c|c|c|}
\hline \multirow{3}{*}{ CADRE } & \multirow{2}{*}{\multicolumn{2}{|c|}{$\begin{array}{c}\text { ABSUTH } \\
\text { TB Training in the } \\
\text { past }\end{array}$}} & \multirow{3}{*}{$\chi^{2}$} & \multirow{3}{*}{$\begin{array}{c}P \\
\text { value }\end{array}$} & \multicolumn{2}{|c|}{ FMCU } & \multirow{3}{*}{$\chi^{2}$} & \multirow{3}{*}{ P Value } \\
\hline & & & & & TB Trainin & the past & & \\
\hline & Yes & No & & & Yes & No & & \\
\hline Doctors & $10(50)$ & $10(50)$ & \multirow{4}{*}{3.57} & \multirow{4}{*}{0.31} & $16(80)$ & $4(20))$ & \multirow{4}{*}{14.45} & \multirow{4}{*}{$<0.02 *$} \\
\hline Nurses & $9(28.1)$ & $23(71.9)$ & & & $12(37.5)$ & $20(62.5)$ & & \\
\hline Lab Sci/Tech & $4(36.4)$ & $10(63.6)$ & & & $5(35.7)$ & $9(64.3)$ & & \\
\hline $\begin{array}{l}\text { Medical Rec. } \\
\text { officers }\end{array}$ & $4(50)$ & $4(50)$ & & & $1(12.5)$ & $7(87.5)$ & & \\
\hline
\end{tabular}

Table 2: Cadre of Health Workers by TB Training in ABSUTH and FMCU

*Statistically Significant

Cadre of health workers by TB training was analysed using chi square test (Table 2). From the table, it could be deduced that there was no statistically significant association between cadre and previous attendance of TB Training in the ABSUTH group. A statistically significant association $(P=0.02)$ was observed between cadre and attendance of TB training in the past among health workers in the FMCU group. Out of the 20 Doctors in the FMCU group, 16(80\%) had attended a training on TB in the past compared to Nurses $9(28.1 \%)$, Laboratory Scientist $4(36.4 \%)$ and medical records officers $4(50 \%)$. 


\begin{tabular}{|c|c|c|c|c|}
\hline Correct Knowledge & $\begin{array}{c}\text { ABSUTH Group } \\
\text { Frequency (\%) } \\
{[n=74]}\end{array}$ & $\begin{array}{c}\text { FMCU } \\
\text { Group } \\
\text { Frequency (\%) } \\
{[n=74]} \\
\end{array}$ & $\chi^{2}$ & p-value \\
\hline Causative organism for TB & $65(87.8)$ & $68(86.5)$ & 5.863 & 0.448 \\
\hline Most commonly affected organ & $65(87.8)$ & $70(94.6)$ & 2.108 & 0.147 \\
\hline Symptoms of TB & $65(87.8)$ & $60(81.1)$ & 1.287 & 0.257 \\
\hline How TB is transmitted & $55(74.3)$ & $48(72.0)$ & 0.142 & 0.706 \\
\hline Test for TB & $18(24.3)$ & $18(24.3)$ & .000 & 1.00 \\
\hline No of Sputum Samples for the Test & $14(18.9)$ & $25(33.8)$ & 4.213 & $0.04^{*}$ \\
\hline Definition of MDRTB & $24(32.4)$ & $31(41.9)$ & 3.978 & 0.264 \\
\hline Test for MDRTB & $35(47.3)$ & $53(71.6)$ & 9.08 & $0.03 *$ \\
\hline Full meaning of 'FAST' & $19(25.7)$ & $11(14.9)$ & 0.102 & 0.074 \\
\hline $\begin{array}{l}\text { Healthcare setting where TB can be } \\
\text { transmitted }\end{array}$ & $46(62.2)$ & $54(73.0)$ & 6.08 & 0.194 \\
\hline Most infectious TB Case & $32(43.2)$ & $51(68.9)$ & 9.903 & $0.002^{*}$ \\
\hline $\begin{array}{l}\text { Environmental factors that enhance TB } \\
\text { transmission }\end{array}$ & $49(62.2)$ & $49(62.2)$ & 6.13 & 0.41 \\
\hline $\begin{array}{l}\text { Face mask protecting health worker } \\
\text { from TB }\end{array}$ & $12(16.2)$ & $21(28.4)$ & 16.05 & $<0.001^{*}$ \\
\hline Mean knowledge score \pm SD & $6.99 \pm 2.59$ & $8.12 \pm 2.84$ & $\mathrm{t}=-2.54$ & $0.012^{*}$ \\
\hline
\end{tabular}

Table 3: Respondents Knowledge of FAST Strategy of TBIC

*Statistically Significant

Table 3 shows knowledge of respondents on the 'FAST' strategy of TB infection control. Among the parameters used in assessing knowledge, there was no statistically significant difference ( $p>0.05$ ) in the ABSUTH and FMCU groups' knowledge of the Causative organism of TB, most commonly affected organ, symptoms of TB, how TB is transmitted, test for TB, full meaning of 'FAST', healthcare setting where TB can be transmitted and environmental factors that enhance TB transmission.

Twenty-five (25) 33.8\% health workers in the FMCU group had correct knowledge of the number of sputum samples for TB test while only $14(18.9 \%)$ had the correct knowledge in the ABSUTH group. This was statistically significant $(P=0.04)$. There was a statistically significant difference $(\mathrm{p}<0.05)$ in the ABSUTH and FMCU groups' knowledge of the test for MDRTB; 54(71.6\%) as against 35(34.3\%) of respondents in the ABSUTH group. Fewer health workers; $32(43.2 \%)$ ) in the ABSUTH group had correct knowledge of 'most infectious case' while $54(68.9 \%)$ of health workers in the FMCU group had correct knowledge. This was statistically significant $(P=0.02)$. The proportion of FMCU staff who knew face mask could not protect the health worker from infection with TB was 21(28.4\%) while among the ABSUTH group, they were $12(16.2 \%)$. This was also statistically significant $(\mathrm{p}<0.05)$.

Knowledge scores were calculated for all respondents out of a possible maximum score of 16 . Mean knowledge score for ABSUTH group $(6.99 \pm 2.59)$ was lower than that of FMCU $(8.12 \pm 2.84)$ this was statistically significant $(p<0.05)$.

\begin{tabular}{|c|c|c|c|c|}
\hline Right Attitude & $\begin{array}{l}\text { ABSUTH Group } \\
\text { Frequency (\%) } \\
{[n=74]}\end{array}$ & $\begin{array}{c}\text { FMCU Group } \\
\text { Frequency }(\%) \\
{[n=74]}\end{array}$ & $\chi^{2}$ & p-value \\
\hline $\begin{array}{l}\text { looking out for coughing patients in waiting } \\
\text { areas in the hospital }\end{array}$ & $56(75.7)$ & $61(82.4)$ & 1.02 & 0.312 \\
\hline $\begin{array}{c}\text { separate coughing patients in waiting areas from } \\
\text { other patients }\end{array}$ & $58(78.4)$ & $58(78.4)$ & .000 & 1.000 \\
\hline $\begin{array}{l}\text { Coughing patients to see the doctor first before } \\
\text { other patients }\end{array}$ & $46(62.2)$ & $52(70.3)$ & 1.087 & 0.297 \\
\hline $\begin{array}{l}\text { finding all of the new cases of TB is an important } \\
\text { task in controlling the disease }\end{array}$ & $72(97.3)$ & $71(95.9)$ & 0.207 & 0.649 \\
\hline $\begin{array}{c}\text { Education of patients about TB is an important } \\
\text { part of their treatment }\end{array}$ & $72(97.3)$ & $73(98.6)$ & 0.340 & 0.560 \\
\hline $\begin{array}{c}\text { Separation of coughing patients will not be seen } \\
\text { as stigmatization }\end{array}$ & $37(50.0)$ & $29(39.2)$ & 1.75 & 0.186 \\
\hline Pre-intervention attitude score \pm SD & $9.12 \pm 2.73$ & $9.14 \pm 2.808$ & $\mathrm{t}=-0.029$ & 0.977 \\
\hline
\end{tabular}

Table 4: Attitude of Health Workers to FAST Strategy of TBIC

Table 4 shows the attitude of health workers in both groups to the 'FAST' strategy of TB infection control. Majority of the respondents; $56(75.7 \%)$ agreed that looking out for coughing patients in waiting areas in the hospital was necessary while 58(78.4\%) agreed that it was necessary to separate coughing patients in waiting areas from other patients. Concerning the need for patient education on TB, 72(97.3\%) agreed it was necessary. Respondents differed on patient separation been seen as stigmatization; more health workers in the ABSUTH group; 37(50\%) agreed separation of coughing patients would not be seen as stigmatization compared to 29(39.2\%) health workers in the FMCU group. Most of the responses obtained on attitude were comparable in both groups. Overall, mean values for attitude scores for the ABSUTH and FMCU groups were 9.12 \pm 2.73 and $9.14 \pm 2.81$ respectively. There was no significant difference (p>0.05) in the attitude scores of both groups to the 'FAST' strategy of TB infection control. 


\begin{tabular}{|c|c|c|c|c|}
\hline Variables & $\begin{array}{c}\text { ABSUTH } \\
\text { n (\%) }\end{array}$ & $\begin{array}{c}\text { FMCU } \\
\text { n (\%) }\end{array}$ & $\chi^{\mathbf{2}}$ & P value \\
\hline Knowledge & & & & \\
\hline Poor & $56(75.7)$ & $47(63.5)$ & & \\
\hline Good & $18(24.3)$ & $27(36.5)$ & 6.72 & $0.010^{*}$ \\
\hline Attitude & & & & \\
\hline Poor & $18(24.3)$ & $17(23.0)$ & & 0.847 \\
\hline Good & $56(75.7)$ & $57(77.0)$ & 0.37 & \\
\hline
\end{tabular}

Table 5: Categories of Knowledge and Attitude of Health Workers in ABSUTH and FMCU Facilities

*Statistically Significant

Table 5 categorises the health workers knowledge and attitude into 'Poor' and 'Good' based a cut off of 8.00 out of a possible 16 scores for knowledge and 8 for attitude out of a possible 12 scores.

A higher percentage of health workers in both ABSUTH and FMCU facilities (82.4\% and 63.5\%) had poor knowledge of the 'FAST' strategy of TB infection control. However, there were more health workers; $27(36.5 \%)$ with good knowledge in the FMCU group compared to the ABSUTH group-18(24.3\%). There was a statistically significant difference $(\mathrm{p}<0.05)$ between the knowledge scores of the health workers in the ABSUTH and FMCU facilities. In the ABSUTH group, $18(24.3 \%)$ had poor attitude to the 'FAST' strategy of TB infection control while a majority 56(75.7\%) had good attitude. The health workers in FMCU had similar categories of attitude with the ABSUTH group and no statistically significant difference in attitude was found.

\begin{tabular}{|c|c|c|c|c|c|c|}
\hline & \multicolumn{5}{|c|}{ Knowledge } \\
\hline $\begin{array}{c}\text { Independent } \\
\text { Variable }\end{array}$ & $\begin{array}{c}\text { Good } \\
\text { knowledge }\end{array}$ & $\begin{array}{c}\text { Poor } \\
\text { knowledge }\end{array}$ & $\begin{array}{c}\text { Crude odds } \\
\text { ratio(c0R) }\end{array}$ & P value & $\begin{array}{c}\text { Adjusted odds } \\
\text { ratio(a0R) }\end{array}$ & $\begin{array}{c}\text { P } \\
\text { value }\end{array}$ \\
\hline Gender & & & & & & \\
\hline Female & 25 & 29 & 1 & & 1 & \\
\hline Male & 15 & 5 & $2.90(1.01-8.35)$ & $0.05^{*}$ & $2.24(0.74-6.80)$ & 0.15 \\
\hline $\begin{array}{c}\text { Previous TB } \\
\text { Training }\end{array}$ & & & & & & \\
\hline No & 15 & 25 & 1 & & 1 & \\
\hline Yes & 25 & 9 & $3.00(1.12-8.01)$ & $0.02^{*}$ & $2.81(1.01-7.99)$ & $0.05^{*}$ \\
\hline
\end{tabular}

Table 6: Multivariate Logistic Regression of Knowledge of 'FAST' Strategy of TBIC Using

Predictor Factors Identified in Univariate Logistic Regression (FMCU Group)

Ref. $=$ Reference

*Statistically Significant

Table 6 shows odds ratios for predictors of knowledge of FAST strategy of TBIC from univariate and multivariate logistic regression at 95\% confidence interval (C.I.) for the FMCU group. Univariate analysis was done for gender, educational level, age, cadre, and previous attendance at TB training. Only gender and previous attendance at TB training showed a statistically significant association at univariate level.

On adjustment during multivariate logistic regression analysis, only previous attendance at TB training was a significant predictor of knowledge of FAST strategy of TBIC. With reference to not previously attending a TB training, having attended a TB training had more than two times increased likelihood of good knowledge; AOR 2.81; 95\% CI (1.01-7.99).

\begin{tabular}{|c|c|c|c|c|c|c|}
\hline \multicolumn{7}{|c|}{ Attitude } \\
\hline $\begin{array}{c}\text { Independent } \\
\text { Variable }\end{array}$ & Good Attitude & $\begin{array}{c}\text { Poor } \\
\text { Attitude }\end{array}$ & $\begin{array}{l}\text { Crude odds } \\
\text { ratio(COR) } \\
\end{array}$ & P value & $\begin{array}{c}\text { Adjusted odds } \\
\text { ratio(AOR) }\end{array}$ & $\begin{array}{c}\mathbf{P} \\
\text { value }\end{array}$ \\
\hline \multicolumn{7}{|l|}{ Age } \\
\hline $20-29$ & 4 & 2 & ref. & & & \\
\hline $30-39$ & 20 & 7 & $0.21(0.03-1.53)$ & 0.12 & $0.20(0.03-1.52)$ & 0.12 \\
\hline $40-49$ & 23 & 1 & $9.58(1.02-91.62) *$ & $0.05^{*}$ & 9.68(1.01-92.8) & $0.05^{*}$ \\
\hline $50-59$ & 12 & 5 & $1.19(0.31-4.60)$ & 0.80 & $1.19(0.31-4.59)$ & 0.80 \\
\hline \multicolumn{7}{|l|}{$\begin{array}{c}\text { Previous TB } \\
\text { Training }\end{array}$} \\
\hline No & & & ref. & & & \\
\hline Yes & & & $1.29(0.43-3.85)$ & 0.65 & $0.88(0.26-2.98)$ & 0.83 \\
\hline
\end{tabular}

Table 7: Multivariate Logistic Regression of Attitude to 'FAST' Strategy of TBIC Using Predictor Factors Identified in Univariate Logistic Regression (FMCU Group)

Ref. $=$ Reference

*Statistically Significant

Table 7 shows odds ratios for predictors of attitude to FAST strategy of TBIC from univariate and multivariate logistic regression at 95\% confidence interval (C.I.). Univariate analysis was done for gender, educational level, age, cadre, and previous attendance at TB training. Only age group 40-49 showed a statistical association at univariate level. 
On adjustment during multivariate logistic regression analysis, only age 40-49 was a significant predictor of attitude to FAST strategy of TBIC. With reference to age 20-29, age group 40- 49 had over nine times increased likelihood of good attitude; AOR 9.68; 95\%CI (1.01-92.8).

\section{Discussion}

This study was a facility based comparative study involving two tertiary health institutions. In terms of cadre of health workers included, this study is similar to others involving Doctors, Nurses, Laboratory Scientist/ Technicians, $[15,16,17]$ but differed in the inclusion of medical records staff who are relevant in the active finding of coughing patients as documented in the FAST strategy guidelines [7].

Findings from this study showed that knowledge of the 'FAST' strategy of TB infection control was poor among health workers in both facilities. Out of the health workers in the ABSUTH group, over $70 \%$ had poor knowledge while only $18(24.3 \%)$ had good knowledge, similarly majority of those in FMCU had poor knowledge with only $36.5 \%$ having good knowledge.

Findings of poor knowledge of TB and strategies for TB infection control among healthcare workers has been documented in other studies $[18,15,16]$. In one study on the knowledge of TB among frontline healthcare workers in rural south-east Nigeria, out of the 52 health workers studied, only $14(27 \%)$ of the respondents had a good knowledge score [15]. In another study in Lima, Peru, only $21.9 \%$ of those surveyed, including just under half of the doctors and nurses, correctly recognized that not all persons with TB will develop symptoms [18].

Furthermore, in a study on Knowledge of MDRTB in Delta State Nigeria, it was observed that $38.5 \%$ of health workers had poor knowledge with regards to MDRTB [19]. This is similar to findings in our study where only $24(32.4 \%)$ health workers in the ABSUTH group had correct knowledge of the definition of MDRTB and 35(47.3\%) knew the test for the diagnosis. This finding is also corroborated by the study in Peru where less than half of the respondents recognized that resistant TB or its spread were consequences of inadequate or incomplete treatment [18]. Another study by Minnery et al also recorded low knowledge rates among participants in questions relating to MDR-TB [16].

In this study, only 19(35.7) health workers in the ABSUTH group and less than $20 \%$ of those in the FMCU group knew the full meaning of 'FAST' while 14(18.9\%) knew the correct number of sputum specimens for diagnosis of TB according to national guidelines. This is corroborated by previous studies $[20,18]$. In a systematic review of 31 studies from 14 countries, results revealed lack of knowledge of national and international TB guidelines among health workers [20]. On knowledge of most infectious case, less than half of the health workers studied knew which case was most infectious. This poor knowledge will lead to poor TB screening. Findings from a study in South Africa observed that inadequate knowledge of TBIC was associated with poor screening for TB [21]. This finding of poor knowledge in this study may be related to the fact that majority of the health workers (63.5\%) had never attended a training on TB in the past. In addition, lack of knowledge of the full meaning of 'FAST 'may be due to the fact that the strategy is new in these facilities and probably limited health workers who participated did not step down the knowledge to others.

With regards to attitude, findings in this study revealed that over two thirds (72.4\%) of the health workers were in agreement over looking out for coughing patients in waiting areas in the hospital and separate coughing patients in waiting areas from other patients (76.4\%). Majority of the health workers $72(97.2 \%)$ agreed that finding all of the new cases of TB is an important task in controlling the disease and education of patients about TB is an important part of their treatment. The health workers in both groups however differed on the fact that separation of coughing patients would not be seen as stigmatization. Only 50\% in the ABSUTH group and 39\% in FMCU group had correct attitude with regards to separation of coughing patients. This may be due to the fact that they had poor knowledge of skills for patient education about TB. The 'FAST' strategy aims at triaging and separating patients discreetly and with respect [8].

Overall, 56(75.7\%) ABSUTH health workers had good attitude towards the 'FAST' strategy of TBIC, similar to the FMCU facility with $57(77 \%)$ health workers having good attitude. Findings of good attitude towards TBIC has been documented by some authors [21,22]. In the study done at Addis Ababa Ethiopia, 87\% of health workers agreed that geographically separating patients with active TB disease from other patients was an important intervention in preventing nosocomial transmission of TB [22]. A study in Delta state Nigeria recorded positive attitude towards MDRTB in $71.9 \%$ of the health workers studied. The findings on attitude in this study however differ from results of a survey on health workers and patients in Iraq. The researchers reported that 54.8\% of the patients had negative attitude towards TB [23], while another study in Nigeria observed that negative attitudes towards patients was a major barrier to patients' adherence to TB treatment [24].

Previous studies have documented predictors of knowledge and attitude among health workers; $[9,25,16]$. This study did not find any association between predictor variables (Gender, educational level, age, cadre, and previous attendance at TB training) and knowledge of and attitude to FAST strategy of TBIC in the ABSUTH group. On the contrary, in the FMCU group predictor variables observed to be significant for knowledge were gender and previous attendance at TB training though following adjustment for age, gender and previous TB training attendance only previous attendance at a TB training was a predictor of good knowledge. This study observed that having attended a TB training had more than two times increased likelihood of good knowledge; aOR 2.81; 95\% CI (1.01-7.99). This is corroborated by findings in a study in Ethiopia, which revealed that training is the strongest determinant of knowledge, aOR 3.386 and $95 \% \mathrm{CI}$ (1.377, 8.330) [25]. However, a study in Peru found age and educational level to have association with knowledge [16]. The nonassociation of previous attendance of TB with knowledge in the ABSUTH group could be due to the fact that the training may have been attended several years earlier and as such recall could be poor. 
With regards to predictors of attitude, the study observed that among health workers in the FMCU group age group 40- 49 had over nine times increased likelihood of good attitude; aOR 9.68; 95\%CI (1.01-92.8). A study in Iraq on knowledge and attitude to TB among health workers observed age and job duration to be associated with knowledge [23].

\section{Conclusion}

Knowledge of health workers on 'FAST' strategy of TB infection Control was poor while they had overall good attitude. Despite the relevance of the 'FAST' strategy to TB case detection and TBIC, the study demonstrated poor knowledge among these health workers. The need for health-workers training and re-training on TB is imperative as a one-off introduction of a new strategy is not enough to sustain the knowledge.

- Statement of Competing Interests: The authors have no competing interests.

- Funding: The authors did not receive any funding for this research.

\section{References}

i. World Health Organisation. (2020). Global TB Report 2020 available at https://www.who.int/tb/publications/global_report/en/

ii. World Health Organization (WHO) (2020). Global TB Progress at Risk. Available @ https://www.who.int/news/item/14-10-2020-who-global-tb-progress-at-risk\#:

iii. WHO. End TB Strategy. (2015). Available @https://www.who.int/tb/strategy/en/

iv. UN General Assembly high-level meeting on Tuberculosis on 26 September 2018 available @https://www.who.int/news-room/events/un-general-assembly-high-level-meeting-on-ending-tb

v. World Health Organization. (2020). Global strategy for tuberculosis research and innovation (WHA73.3), Seventy-third World Health Assembly Geneva: (https://apps.who.int/gb/ebwha/pdf_files/WHA73/A73_R3en.pdf, accessed 27 November 2020).

vi. Centre for Disease Control. (2014). Health Care Providers and TB Program Materials by Topic Internet [cited 2020 Nov 27]. Available from: http://www.cdc.gov/tb/education/corecurr/pdf/chapter7.pdf

vii. TB Care II. (2013). FAST;A Tuberculosis Infection Control Strategy. . p. 1-11.

viii. Federal Ministry of Health Department of Public Health (2014). NT and LCP. FAST; A Tuberculosis Infection Control Strategy [Internet]. [Cited 2015 Sep 27]. Available from:

https://www.google.com.ng/?gws_rd=ssl\#q=Fast+tb+strategy+in+nigeria

ix. Demissie Gizaw G, Aderaw Alemu Z, Kibret KT. (2015). Assessment of knowledge and practice of health workers towards tuberculosis infection control and associated factors in public health facilities of Addis Ababa, Ethiopia: A cross-sectional study. Arch public Heal = Arch belges santé publique [Internet]. [Cited 2020 Nov 18];73(1):15. Available from:

(http://www.pubmedcentral.nih.gov/articlerender.fcgi?artid=4377015\&tool=pmcentrez\&rendertype=abstract )

x. Department of Public health, National Tuberculosis and Leprosy Control Programme. (2015) National Tuberculosis , Leprosy and Buruli ulcer Management and control Guidelines 6th Edition. . p. 8-74.

xi. Chughtai AA, Seale H, Chi Dung T, Maher L, Nga PT, MacIntyre CR. (2015) Current practices and barriers to the use of facemasks and respirators among hospital-based health care workers in Vietnam. Am J Infect Control [Internet]. [cited 2015 Sep 28];43(1):72-7. Available from:

http://www.ajicjournal.org/article/S0196655314012425/fulltext

xii. Woith W, Volchenkov G, Larson J. (2012). Barriers and motivators affecting tuberculosis infection control practices of RussiaBarriers and motivators affecting tuberculosis infection control practices of Russian health care workers.n health care workers. Int J Tuberc Lung Dis [Internet]. [cited 2020 Nov 26];16(8):1092-6. Available from:

http://www.pubmedcentral.nih.gov/articlerender.fcgi?artid=3685429\&tool=pmcentrez\&rendertype=abstract

xiii. Solomon T, Shiferaw M, Abreham W, Tayu B, Klinkenberg E, Loha E. (2014). Assigning focal persons to notify more tuberculosis patients: lessons learned in southern Ethiopia. Public Heal action [Internet]. 2014 Dec 21 [cited 2020 Nov 25];4(Suppl 3):S18-24. Available from:

http://www.pubmedcentral.nih.gov/articlerender.fcgi?artid=4542067\&tool=pmcentrez\&rendertype=abstract

xiv. Onwasigwe C. (2010). Principles and Methods of Epidemiology. Second Edi. Enugu: El Demark; 143-157 p.

xv. Ukwuaja K . (2013). Frontline healthcare workers' knowledge of tuberculosis in rural south-east Nigeria. African J Respir Med [Internet]. ;9(1):7-10. Available from:

http://www.embase.com/search/results?subaction=viewrecord\&from=export\&id=L372622239\n

http://www.africanjournalofrespiratorymedicine.com/articles/september_2013/AJRMSept7-10

new.pdf \nhttp://sfx.ub.rug.nl:9003/sfx_local?sid=EMBASE\&issn=17475597\&id=doi:\&at

xvi. Minnery M, Contreras C, Pérez R, Solórzano N, Tintaya K, Jimenez J, et al. (2013). A cross sectional study of knowledge and attitudes towards tuberculosis amongst front-line tuberculosis personnel in high burden areas of Lima, Peru. PLoS One [Internet]. Public Library of Science; [cited 2020 Apr 21];8(9):e75698. Available from: http://journals.plos.org/plosone/article?id=10.1371/journal.pone.0075698\#pone.0075698.s001

xvii. Tenna A, Stenehjem EA, Margoles L, Kacha E, Blumberg HM, Kempker RR, et al. (2015) Infection Control Knowledge, Attitudes, and Practices among Healthcare Workers in Addis Ababa, Ethiopia. Infect Control Hosp Epidemiol [Internet]. Cambridge University Press; [cited 2021 Jan 18];34(12):1289-96. Available from: http://www.journals.cambridge.org/abstract_S0195941700034457 
xviii. Kiefer EM, Shao T, Carrasquillo O, Nabeta P, Seas C. (2019)Knowledge and attitudes of tuberculosis management in San Juan de Lurigancho district of Lima, Peru. J Infect Dev Ctries [Internet]. [cited 2020 Nov 22];3(10):783-8. Available from: http://www.jidc.org/index.php/journal/article/view/20009280

xix. Isara A, Akpodiete A. (2015). Concerns about the knowledge and attitude of multidrug-resistant tuberculosis among health care workers and patients in Delta State, Nigeria [Internet]. Vol. 18, Nigerian Journal of Clinical Practice. [cited 2020 Nov 15]. p. 664-9. Available from: http://www.ajol.info/index.php/njcp/article/view/119448

xx. Van der Werf MJ, Langendam MW, Huitric E, Manissero D. (2012). Knowledge of tuberculosis-treatment prescription of health workers: a systematic review. Eur Respir J [Internet]. [cited 2020 Sep 28];39(5):1248-55. Available from: http://erj.ersjournals.com/content/39/5/1248.short

xxi. Kanjee Z, Catterick K, Moll AP, Amico KR, Friedland GH. (2011). Tuberculosis infection control in rural South Africa: survey of knowledge, attitude and practice in hospital staff. J Hosp Infect [Internet]. Elsevier; [cited 2020 Sep 28];79(4):333-8. Available from: http://www.journalofhospitalinfection.com/article/S0195670111003379/full text

xxii. Tenna A, Stenehjem EA, Margoles L, Kacha E, Blumberg HM, Kempker RR, et al. (2013). Infection Control Knowledge, Attitudes, and Practices among Healthcare Workers in Addis Ababa, Ethiopia. Infect Control Hosp Epidemiol [Internet]. Cambridge University Press [cited 2021 Jan 18];34(12):1289-96. Available from: http://www.journals.cambridge.org/abstract_S0195941700034457

xxiii. Hashim DS, Al Kubaisy W, Al Dulayme A. (2003). Knowledge, attitudes and practices survey among health care workers and tuberculosis patients in Iraq. East Mediterr Heal J = La Rev santé la Méditerranée Orient $=$ alMajallah al-șiḥhīyah li-sharq al-mutawassiț [Internet]. [cited 2020 Sep 18];9(4):718-31. Available from: http://www.ncbi.nlm.nih.gov/pubmed/15748069

xxiv. Ibrahim LM, Hadjia IS, Nguku P, Waziri NE, Akhimien MO, Patrobas P, et al. (2014). Health care workers' knowledge and attitude towards TB patients under Direct Observation of Treatment in Plateau state Nigeria, 2011. Pan Afr Med J [Internet] [cited 2020 Oct 19];18 Suppl 1:8. Available from: http://www.pubmedcentral.nih.gov/articlerender.fcgi?artid=4199343\&tool=pmcentrez\&rendertype=abstract

xxv. Temesgen C, Demissie M. (2014). Knowledge and practice of tuberculosis infection control among health professionals in Northwest Ethiopia; 2011. BMC Health Serv Res [Internet]. 2014 Jan [cited 2019 Sep 28];14(1):593. Available from: http://www.biomedcentral.com/1472-6963/14/593 